\title{
Jornalismo e modelos de mulher: a construção de sentidos das narradoras de TPM
}

\author{
Patricia Rocha*, Marcia Benetti*:
}

\begin{abstract}
RESUMO
A imprensa feminina atua na construção de modelos de mulher a partir de uma fala hegemonicamente normativa e pedagógica. Lançada em 2001, a revista Trip para Mulher, a TPM, caracterizada por narradoras que assumem sua presença no texto e compartilham sua intimidade, afirma constituir-se como uma ruptura aos manuais que ensinam como ser mulher e reiteram estereótipos historicamente construidos. Este artigo busca confrontar essa proposta de ruptura a partir da análise dos sentidos produzidos sobre si mesmas pelas narradoras da revista. A partir da análise de discurso, verificamos que as narradoras constroem imagens de mulher a partir de seis formações discursivas "mulherzinha", "fora do padrão", "sábia e experiente", "dona do próprio destino", "solteira orgulhosa" e "repórter aventureira". As conclusōes indicam que, embora TPM promova certas rupturas, converte estas formas de suposta resistência em novos modos de regrar a feminilidade.
\end{abstract}

Palavras-chave: jornalismo; imprensa feminina; análise de discurso; narrador

\section{ABSTRACT}

The feminine press contributes in the construction of female models from a hegemonially normative and pedagogical discourse. Released in 2001, the Brazilian magazine Trip para Mulher [Trip for Women], also called TPM, characterized by female narrators who affirm their presence in the text and share their intimacy with the readers, states that it is a magazine which breaks with those manuals which are aimed at teaching how to be a woman and reinforcing historically built stereotypes. The analysis revealed that the magazine's narrators build images of women from six discourse formations - "lady-like woman", "social outlaw", "owner of her own destiny", "proud single woman" e "be anadventurous reporter". Although TPM do breaks with some rules in terms of female stereotypes, the magazine converts these forms of pretentious resistance in new ways of ruling what feminine is.

Key-words: journalism; feminine press; discourse analysis, narrator

\footnotetext{
* Iornalista c mestre em Comunicação c Informação pela Universidade Federal do Rio Grande do Sul (PPGCOM/UFRGS).

* Jornal lista, doutora em Comunicação e Semiótica pela PUC-SP e docente do Programa de PósGraduação em Comunicação e Informação da Universidade Federal do Rio Grande do Sul (PPGCOM/UFRGS).
} 


\section{Você, leitora, e eu}

As revistas segmentadas indicam ao público os modos de ser para se enquadrar no modelo bem-sucedido de pessoa que cada publicação constrói, captando tendências de comportamento e consumo, capitalizando-as e colaborando para a construção de identidades sociais (MIRA, 2001).

Nas revistas femininas, esse movimento é explícito: com verbos no imperativo, as publicações apresentam às leitoras dicas de comportamento e consumo, prescrevendo modelos de mulher. Trata-se do saber de narração construído desde o século XVIII, quando se consolidou a imprensa para mulheres - com pouca instrução e posição secundária na sociedade, moças e senhoras tinham a seu dispor publicações destinadas a ensiná-las a ser boas mães, esposas e donas de casa. A despeito das conquistas femininas no âmbito social, cultural e político dos séculos seguintes, as estratégias narrativas das revistas a elas destinadas permanecem: a "armadilha lingüística" de uma fala coloquial, em que as leitoras são chamadas de "você", como numa conversa entre amigas, que mascara o tom autoritário e normativo (BUITONI, 1990).

Apesar dos assuntos aparentemente superficiais da maioria destas publicações (moda, casa, beleza e relacionamentos amorosos), Buitoni (1981) destaca que a imprensa feminina pode ser mais carregada de carga ideológica do que a imprensa de referência. Centrada em temáticas de foro privado, a imprensa feminina criou uma temporalidade própria, "do corpo, do lar, da transformação pessoal" (BRAGA, 2005), predominantemente desconectada do noticiário vigente $\mathrm{e}$, assim, do "mundo real".

Nesse contexto, a revista Trip Para Mulher, a TPM, da editora Trip, apresenta-se às leitoras como uma exceção. Em seu lançamento, em 2001, anunciava no editorial ser uma alternativa às demais revistas femininas, ironizando a fala autoritária 1, o culto à beleza e a falta de assuntos reflexivos que resultavam na construção de estereótipos femininos. Já no primeiro número, TPM exibia uma singularidade que a destacava das demais publicações femininas, que constroem seus modelos de mulher por meio da confidência de olimpianas 2 e de leitoras (em depoimentos às vezes anônimos) e por meio da legitimação de especialistas3, autorizados por sua formação profissional. Em TPM, o 
falar de si e a legitimidade para fazer juizos de valor fundem-se na narrativa auto-referente de jornalistas e colaboradoras: são clas os personagens recorrentes da revista, cujas vidas são narradas a cada edição, como em um blog ou um reality show. O falar de si toma forma não apenas em colunas e crônicas, mas também é narrado em meio a reportagens e seções da revista, muitas vezes inspiradas na propria biografia das narradoras e ilustradas com fotos delas, que assumem o posto de olimpianas.

As narradoras de TPM rompem com a narrativa jomalística tradicional, que oculta a figura do narrador como forma de garantir que os fatos falam por si, de acordo com os ideais de objetividade e imparcialidade, herdados da concepção positivista. Em consonância a esta suposta neutralidade possivel, convencionou-se uma fala impessoal, predominantemente em terceira pessoa - a forma verbal da não-pessoa (BENVENISTE, 2005; MAINGUENEAU, 2005; RODRIGUES, 1997). Embora essa suposta isenção esteja na base da credibilidade jornalistica, as teorias construcionistas da noticia demonstram que tanto o exercício da profissão quanto seu produto estão sujeitos a diferentes condicionantes, como a rotina produtiva, a cultura profissional, a organização da cmpresa $c$ até a influência pessoal do jornalista, modulada por sua trajetória de vida e profissional (SERRA, 2004). Essa perspectiva substitui a imagem de um jornalista passivo, que apresenta fatos, por um sujeito ativo, que "tanto trata da realidade, quanto a recria" (RESENDE, 2002, p.19).

No jornalismo e em qualquer outra narrativa, não há como ignorar a existência de um "cu" que narra. Como lembra Motta (2004), nenhuma narrativa é desinteressada e cada narrador estrutura o discurso a partir dos efeitos que pretende provocar no leitor, que, por sua vez, reconstrói o discurso na leitura. Assim, no caso da TPM, explicitar a presença e as características pessoais do narrador constitui uma estratégia de contato com o público e de convencimento da relevância da mensagem tanto quanto camuflar a presença de quem narra. Ao abrir mão da impessoalidade da narração em terceira pessoa, que corresponde à expectativa oficial de neutralidade e objetividade (MEDINA, 1996), as narradoras de TPM evocam o narrador da tradição oral: "alguém que tinha a autoridade para narrar, alguém que vinha de outros tempos ou de outras terras, tendo, por isso, experiência a comunicar e conselhos a dar a seus ouvintes atentos" (LEITE, 2005, p.5). Conservam a cssência 
desse narrador ao contar o que elas mesmas viram, viveram e, com a sabedoria acumulada das tantas experiências que dizem viver, aconselhar a interlocutora - sendo esta possibilidade de troca de experiências a verdadeira natureza da narrativa, segundo Benjamin (1985)4. Assim, mesmo que TPM resista à fórmula do manual de dicas que caracteriza outras revistas femininas, as narradoras da publicação podem, por meio da narração de suas próprias experiências, instruir implicitamente as leitoras.

O narrador em primeira pessoa constitui-se como mais um personagem da narrativa: não se trata de uma correspondência real da pessoa que escreve (o jornalista), mas de uma construção discursiva que enfatiza determinados traços psicológicos e dilui outros. Considerando ainda que protagonista é aquele que move a ação (MOTTA, 2004), as narradoras podem também assumir este papel quando têm como fio condutor do texto sua atuação no processo produtivo jornalístico ou quando fazem da própria vida o ponto de partida de uma matéria. Da mesma forma que narrar as próprias memórias ou seu diário íntimo é a maneira mais plena de um narrador 52 se fazer presente no texto (BORNEUF e OUELLET, 2002), no jornalismo os personagens têm maior aceitação quanto mais pedaços de vida compartilham (FONTCUBERTA, 1993) - premissa fundamental para que se dê a "identificação virtual" (MOTTA, 2004), quando as pessoas transpõem as histórias narradas para suas próprias vidas. Nas revistas femininas, essa identificação já era buscada por meio de relatos em primeira pessoa de leitoras e celebridades e da fala coloquial, incluindo o uso de "nós" e "você", radicalizados por TPM com o "eu". Os pronomes pessoais adotados no texto, portanto, não são gratuitos. São estratégias pelas quais a gramática da produção procura capturar o público (VIZEU, 2005), em que o "nós", por exemplo, funciona como uma convocação explícita ao leitor para dar a ele a sensação de que é co-participante daquele produto jornalístico -e dos modelos de comportamento e consumo ali difundidos.

O pronome "você" não remete apenas à leitora mas também ao "eu" que escreve, porque, em um discurso, só um "eu" pode designar um "tu". Ao contrário da terceira pessoa, que pode se referir tanto a um sujeito como a uma coisa (a "não-pessoa"), "eu" e "tu" remetem, cada um, a pessoas específicas e que são indissociáveis: todo "eu" fala para um "tu" que, à medida que toma a palavra, assume o papel de 
locutor. Assim, a correlação subjetiva eu/tu pressupõe um diálogo implicito e também a possibilidade de transcendência: cada "eu" é um "tu" em potencial e vice-versa (BENVENISTE, 2001; MAINGUENEAU, 2005). A relação eu/tu, eu/outro é reversivel, e esta é uma condição para que haja discurso.

Cada "eu" escrito pelas narradoras de TPM remete a um chamamento para que a leitora se identifique com aquela que narra. $A$ construção de sentido sobre si mesmas destas narradoras implica que lugares de inscrição elas convidam suas leitoras a ocupar. Portanto, interessa aqui como estas narradoras se apresentam discursivamente às leitoras, que ethos constroem no texto (MAINGUENEAU, 1997): a personalidade que, a partir do discurso, é atribuída ao locutor, delineada não apenas pelas idéias enunciadas mas "por uma maneira de dizer que remete a uma maneira de ser" (MAINGUENEAU, 2005, p. 99, grifos do autor). É essencial, assim, analisar não apenas o que se diz, mas como se diz.

É preciso compreender os sentidos contidos na fala destas narradoras auto-referentes, pertencentes a uma revista que se diz de ruptura, e contrapô-los à construção de modelos de mulher na imprensa feminina, desde as beldades etéreas, imagem fartamente evocada em publicações de fins do século XIX, passando pela mulher como "metade ideal do gênero humano", a dona de casa e esposa caprichosa, a solteira assertiva na conquista (BUITONI, 1990), até a multifuncional (FUJISAWA, 2006), que dá conta de tudo - corpo, casa, profissão, amor e sexo. Com base neste movimento de formatar modelos de identificação, é possivel compreender a imprensa feminina como um "termômetro de costumes" que estampa o que é ser mulher em um determinado contexto. Assim, as revistas para mulheres colaboram decisivamente na construção e desconstrução das identidades sociais femininas (BRAGA, 2003; MIRA, 2001), se não individualmente, influenciando o repertório de cada leitora, coletivamente, a partir da imagem de mulher que será predominantemente percebida $\mathrm{e}$ compartilhada pela sociedade em uma dada época.

O que "ensinam" implicitamente as narradoras de uma revista que se diz de ruptura, com narradoras que fazem confidências intimas c cmitem juizos de valor sobre os mais variados temas? Em que medida as mulheres que tomam forma neste falar de si rompem com os modelos 
construídos pela imprensa feminina ao longo de sua história ou se alinham a eles?

\section{Os sentidos construídos}

É a partir da fala que o narrador se configura como sujeito aos olhos do leitor e aos seus próprios. A chave para compreender os sentidos que ele produz está no discurso - e a metodologia que utilizamos para compreendê-lo é a análise de discurso francesa. O texto, nesta concepção, é a unidade de análise, mas não a delimitação do objẹto, uma vez que o discurso é uma construção que excede o texto, carregando as marcas da historicidade, da própria língua, do contexto em que se está inserido e de discursos anteriores que inconscientemente o sujeito evoca na enunciação (MAINGUENEAU, 1997; ORLANDI, 2005). É chamada de interdiscurso a presença desta memória discursiva acionada no ato de dizer, embutindo na enunciação outros sentidos historicamente construídos.

Essa dinâmica discursiva se dá no bojo do que Pêcheux denominou de duplo esquecimento: o primeiro, da ordem do inconsciente, nos dá a ilusão de sermos a origem do que dizemos; o segundo, da ordem da enunciação, produz a ilusão de uma relação direta entre pensamento, linguagem e mundo, de modo que cremos que o que dizemos só poderia ser dito daquela maneira (ORLANDI, 2005). Apagamos duas idéias centrais: que não somos os criadores originais de nossas falas e que poderíamos ter enunciado outros ditos (e silenciado outros não-ditos) ou feito outras escolhas. Nesse processo, "naturaliza-se" o que na verdade é construção social e histórica - em uma palavra, ideologia.

A partir destas proposições, podemos pensar o discurso jornalístico como "dialógico; polifônico; opaco; ao mesmo tempo efeito e produtor de sentidos; elaborado segundo condições de produção e rotinas particulares; com um contrato de leitura específico, amparado na credibilidade de jornalistas e fontes" (BENETTI, 2006). É dialógico porque remete à interdiscursividade, que, sem que percebamos, constitui os sentidos do que dissemos, e à intersubjetividade, uma vez que um discurso só se dá entre sujeitos. Pode ser (mas não obrigatoriamente $o$ é) polifônico, na medida em que apresenta vozes diferentes. E é opaco 
porque seus sentidos não são transparentes, apesar da ilusão de literalidade em que o jornalismo se ampara.

Para compreender os sentidos presentes na opacidade do discurso jornalistico é preciso entender quem fala, de onde fala, como fala e para quem fala. Na perspectiva da análise de discurso, é basilar o jogo de imagens e auto-imagens que permeia a interlocução. Para Pêcheux, destinador e destinatário representam nos processos discursivos lugares de fala determinados na estrutura da sociedade denominados por cle de formações imaginárias (Fls): imagens que destinador e destinatário atribuem a si mesmo $\mathrm{e}$ ao outro. As Fls podem ser resumidas $\mathrm{cm}$ quatro perguntas. O destinador questionaria: "Quem sou eu para the [ao destinatário] falar assim?" " "Quem ć elc para que eu lhe fale assim?". E o destinatário se perguntaria "Quem sou eu para que ele me fale assim?" e "Quem ć cle para que me fale assim?" (PÊCHEUX, 1990, p.83). Interessa aqui o destinador (narrador) e os sentidos produzidos sobre si mesmo: quem as narradoras de TPM pensam ser para falar assim às leitoras? É necessário, portanto, mapear as posições de sujeito que ocupam, entendidas aqui como "lugares construídos fora do discurso em questão, segundo determinações culturais, sociais e históricas", e o contexto de produção desses discursos (BENETT1, 2006).

A análise inicia-se a partir do próprio texto para chegar à sua cxtcrioridade c à sua anterioridade constitutivas, $\mathrm{c}$ o primciro passo para a compreensão dos sentidos presentes é identificar as formações discursivas (FDs). regiões de sentidos em que se busca reunir todas as marcas textuais que convergem para um sentido nuclear estabelecido na obscrvação do corpus (BENETTI, 2006). As FDs tomam forma a partir do movimento de paráfrase, por meio do qual o tex to reitera um mesmo sentido ao longo de diferentes seqüências discursivas (SDs), trechos arbitrariamente recortados pelo analista em função de sua operacionalidade metodológica e relevância de conteúdo analítico. Para compreender os sentidos construidos pelas narradoras sobre si mesmas, analisamos seis edições de TPM, de setembro de 2005 a agosto de 2006, com média de 100 páginas c tiragem de 35 mil cxemplares. Foram analisados 156 textos 5 , privilegiando as matérias $\mathrm{cm}$ que as autoras constroem sentidos sobre si mesmas. Ao todo, analisamos 252 seqüencias discursivas e encontramos seis formações discursivas principais que condensam os sentidos das narradoras de TPM sobre si 
mesmas. A seguir, trazemos estas FDs, assinalando em cada SD6 as marcas de sentido mais expressivas que reforçam o sentido nuclear.

\subsection{Mulherzinha}

$T P M$ afirma ser uma revista fora dos padrões, mas isso não a impede de reiterar modelos de mulher construídos deśde os primórdios da imprensa feminina e atualizados hoje nos mesmos suplementos que a publicação costuma ironizar. Ganha corpo no discurso das narradoras a "mulherzinha", denominação que designa a imagem feminina sintonizada com os estereótipos historicamente construídos na imprensa, da mulher como uma dádiva da natureza à mitificação contemporânea da multifuncionalidade feminina. Nesta FD, cujo sentido nuclear foi identificado em $29 \% 7$ das SDs analisadas, a "mulherzinha" apresentase cheia de qualidades inatas como aqueles modelos de mulher que Buitoni (1981) identificou nas revistas da virada do século XX, atualizando o mesmo discurso que apresenta as mulheres como uma entidade superior, aclamadas por sua beleza, capacidade de afeto e sensibilidade:

Topar com mulheres como Suzana é sempre um prazer. Porque ela nos faz ver aquilo que sabemos, mas que às vezes duvidamos: mesmo tendo que cruzar a perna aqui e ali, somos capazes de chegar longe, contando apenas com nossa intuição, criatividade e sensibilidade. E, no meio do caminho, ser mãe e esposa. (SD6)

A construção da fẹminilidade é empreendida no avesso das características supostamente masculinas, como racionalidade e objetividade. Mesmo que o enunciado apresente os atributos "tipicamente femininos" de forma positiva, é inegável a reiteração de sentidos que converge para a naturalização de traços convencionalmente relacionados a cada gênero, como se fossem imanentes e não resultantes da construção de representações ao longo da história. A enunciação constrói uma mulher sensível, intuitiva e capaz de chegar longe, "mesmo tendo que cruzar a perna aqui e ali": o discurso da revista que se diz de ruptura evoca até o estereótipo da mulher que ascende profissionalmente a partir de dotes estéticos. Além da carreira, a "mulherzinha" tem (ou deveria ter) a casa, os filhos e a relação amorosa sob controle - o mito da "mulher multifuncional" (FUJISAWA, 2006): 
Cada vez tenho menos tempo para cuidar da minha casa. Com emprego novo e com minha filha Joana sempre precisando de atenção, se não abro o olho a decoração do nosso apartamento fica capenga. (SD322)

Como as senhoras dos séculos XVIII e XIX, a mulher superpoderosa dos anos 2000 é instada a agradar seu marido. Para isso, além de uma casa em ordem e de filhos educados, é cada vez mais importante cuidar de si mesma, principalmente do corpo. Mais uma vez, os sentidos reiterados no discurso das narradoras as aproximam do padrão de mulher que a publicação critica - aquela que age em função do homem e da possibilidade de estabelecer e manter uma relação amorosa.

No espelho do elevador me achei bonita, tão bonita que era um desperdício para uma mulher... sozinha! Conclusão: preciso de mais 20 anos de análise para conseguir jantar sozinha em um restaurante e gostar disso. Por enquanto, continuarei usuária do dellivery do Ritz! (SD293)

As narradoras atualizam o discurso que remete à beleza feminina como investimento que encontra sua razão de ser na aprovação masculina, remontando ao mesmo discurso que por séculos tem colocado a mulher na tensão entre ser sujeito de seus próprios desejos e ser objeto dos desejos do homem, como definiram Morin (2005) e Passerini (1991). Tomam forma os mesmos ideais difundidos hegemonicamente na imprensa para mulheres, em que o cuidado com a aparência é vital na construção das identidades femininas (BRAGA, 2005).

Tudo o que eu queria era voltar a ser mulher, voltar a existir, passar rímel, alongador de cílios e usar minha bota prateada com salto agulha e minhas unhas vermelhas. Eu não agüentava mais. (SD16)

No discurso "mulherzinha", a condição feminina está amparada também na embalagem, com cosméticos, roupas, acessórios e grifes não raro citadas nominalmente. Consumir é esforçar-se para ser bonita, estilosa, referendando a idéia de que ser mulher é subordinar-se aos deveres para com o corpo. Completa-se, assim, o conjunto de sentidos que remetem ao que chamamos de "ser mulherzinha": incensada pelos seus atributos ditos naturais e convicta das múltiplas exigências a que deve atender como mulher. 


\subsection{Fora do padrão}

As narradoras de TPM apresentam-se como destoantes da maioria das mulheres. Elas constroem uma imagem de si mesmas que remete à singularidade, a um estilo de vida e visão de mundo que afrontam o convencional - a antítese do previsível. Paralelamente, referendam o espaço que $T P M$ busca no mercado de revistas femininas: ser diferente de todas as demais. "Fora do padrão" é como denominamos esta FD, que representa $22 \%$ das SDs analisadas: os sentidos predominantes demarcam uma posição contrária à regra por meio da reiteração da diferença, convergindo para reafirmar a singularidade da narradora.

[...] como uma mulher alta, voluptuosa, digamos assim, e com tanta tatuagem quanto um passaporte de rockstar, estou acostumada a chamar atenção para o bem ou para o mal, e, mesmo fora dos padrões, ainda assim eu sou mulher. (SD13)

É apenas isso o que posso deixar de herança: a noção de que crescer, mesmo fora dos padrões, não é sofrer, a certeza de que a vida não pode ser levada muito a sério, de que o normal é ser diferente. (SD264)

No tensionamento entre a singularidade e as convenções sociais às quais presumivelmente as narradoras deveriam se submeter, elas demarcam sua diferença como peça-chave de um modo de ser que lhes garante visibilidade e distinção. Ser desviante evoca autenticidade. Desse modo, constroem sua posição de resistência contrariando expectativas e unanimidades: não apenas são diferentes como também têm coragem de escancarar sua singularidade, mesmo quando isso aparentemente remete ao desajuste de quem rompe com a norma - o que as tornaria ainda mais singulares.

Assim como destacam suas qualidades, as narradoras também relatam supostos erros e situações vexatórias por que passaram, admitem que não sabem ou não conseguem fazer determinadas coisas e não hesitam em divulgar seus defeitos. Rompem, assim, com o padrão de perfeição que vem tomando forma na imprensa feminina, o ideal contemporâneo de mulheres que podem e devem ter um excelente desempenho em múltiplos papéis. Simultaneamente a esta ruptura possivel, ao proclamarem suas singularidades, as narradoras de TPM constroem outro padrão para suas leitoras: ser "do contra". Para ser "extraordinário", no que tange àquilo que rompe com o ordinário da 
vida, não bastaria, à mulher de $T P M$, ser ela mesma, e sim surpreender os demais.

\subsection{Sábia e experiente}

A mulher que emerge no discurso das narradoras de TPM é também dona da verdade, habilitada a expressar juízos de valor sobre as pessoas e o mundo que a rodeia. Chamamos esta formação discursiva, percebida em 17\% das SDs, de "sábia e experiente": a mulher que se ampara na experiência vivida para julgar e aconselhar os outros paralelamente constrói sentidos sobre si mesma que remetem a sua esperteza e a sua sabedoria acumuladas, que as distinguem das demais, como ilustram as SDs a seguir:

[A guarda compartilhada] Funciona assim: combina-se que a criança passa a mesma quantidade de tempo com o pai e a com a mãe. Por exemplo: segunda e quarta com um, terça e quinta com outro e fins de semana alternados com o pai e a mãe. Eu conheço bem o esquema, pois, há nove anos, meu enteado se reveza entre nossa casa e a da mãe dele. Funciona maravilhosamente bem, se você seguir umas regrinhas básicas. (SD298)

Criamos um detector de mentiras especializado em pegar as loucuras que os homens inventam. Sim, ele funciona. Não, não somos cientistas. Mas somos espertas e já fomos alvo de muita mentira nesta vida. Então, pode acreditar (SD382)

As narradoras de TPM dizem ser vividas o bastante para terem muita convicção acerca do mundo. São "gente que faz" e, portanto, sabe. Podem dizer sentenças taxativas, porque seu estilo de vida - dos vividos, espertos - as habilita para isso:

Imagino uma paulistana dizendo a outra: "Olha, estou cheia de tempo livre, vivendo muito bem". Não consigo pensar qual seria a cara da interlocutora. A falta de tempo é um vício para a gente que mora nessa paulicéia desvairada. Não ter tempo é supercool. Só que é tudo mentira. A gente até trabalha bastante, mas tem tempo, sim. [...] Soltar um: "Não te liguei porque fui à praia na segunda à tarde" não costuma ser vergonha no Rio. Aqui em São Paulo, imagina! A gente simplesmente não tem tempo. Trabalhamos de sol a sol. E terminamos o dia falando no botequim: "Meu dia foi uma loucura". Foi nada. Você passou o dia todo "vendo quem estava no Orkut", que cu sei. (SD139) 
As narradoras de TPM não se limitam a ter opiniões. Quando se apresentam como sábias e experientes, naturalizam sua posição de sujeito autorizado a julgar. Nesta condição, não se furtam a fazer juízos de valor ou ser taxativas sobre o mundo e as pessoas, porque se apresentam como legitimadas para tanto: são espertas e seguras o suficiente para dizer às leitoras como ser, pensar e o que fazer. Assim, não são apenas mulheres intercambiando experiências, como preconizou Buitoni (1990), em oposição à fala normativa dos especialistas: as "sábias e experientes", muitas vezes, reiteram à sua maneira a fala autoritária e instrutiva que historicamente se consolidou na imprensa para mulheres.

\subsection{Repórter aventureira}

Ser jornalista é uma grande aventura - ao menos para quem trabalha na TPM ou é sua colaboradora. Ao falarem de si mesmas, as narradoras da revista não constroem sentidos apenas sobre elas próprias ou sobre ser mulher, mas também sobre ser jornalista. Na análise dos sentidos produzidos no discurso, interessa, portanto, compreender que imagem jornalistas e colaboradoras produzem acerca da profissão que exercem na revista:

Saí daquele carro achando que tudo na vida é possivel. E que dirigir é bem mais fácil do que andar de esqui ou snowboard - isso, sim, uma missão impossível que eu já tentei praticar em nome do jornalismo e desta revista que você lê (TPM \# 35). Daquela vez, sem sucesso. Dessa vez, me aguardem. (SD33)

Denominamos esta construção de sentidos, presente em 14,5\% das SDs, de "ser repórter aventureira", uma imagem que mitifica a profissão, mas não pela figura idealizada do jornalista como um obstinado caçador de notícias, que embasa a cultura profissional (TRAQUINA, 2005). A FD remete à experimentação de momentos divertidos e surpreendentes, mais conectada à vida pessoal da repórter do que à sua rotina profissional - uma dose extra de emoção para estas mulheres. Ao contrário da imagem idealizada no cinema, de jornalistas dedicados em tempo integral à busca de um furo de reportagem, "ser repórter aventureira" em TPM implica fazer do exercício jornalístico uma extensão do seu estilo de vida, e não o contrário. O jornalismo praticado na revista é apresentado como algo tão fora do padrão quanto a imagem que as narradoras constroem de si mesmas. 
Sendo supostamente contrárias às unanimidades, as repórteres aventureiras também se diferenciam dos demais jornalistas:

Se você não é jornalista, sorte a sua. Isso significa que você nunca foi a uma festa de jornalistas ou a um bar freqüentado por eles. Sabemos do que estamos falando! Festa de jornalista costuma ser uma coisa caida onde toca Tim Maia e mulheres usam tubinho preto. $\mathrm{E}$ os bares... bem, jornalista tem mania de falar sobre coisas chatas, como, por exemplo, a burrice alheia (a gente acha que só a gente é inteligente) e demissões. Já pensou uma noite com várias pessoas conversando sobre "os cortes que devem acontecer na empresa?". Medo, não? Pois tem gente que gosta. Acaba de ser aberto em São Paulo um bar que foi feito justamente com o conceito de ser um bar de jornalista. Socorro! [...] Para o bar ser perfeito (não, não tivemos coragem de ir lá conferir) agora só falta que: [...] Os assuntos girem em torno dos cortes na Abril, as mudanças no projeto gráfico da Folha e a última capa da Veja. Quando chegar a comida, eles vão aproveitar e comparar o bandejão da Folha ao do Estado. Ah, e os freqüentadores serão vários Feitosas, que, para quem não sabe, é o apelido que inventaram aqui na editora para aquele jornalista típico, que só fala sobre mudanças na chefia e demissões. (SD80)

As narradoras constroem duas instâncias discursivas: as integrantes da redação de TPM, somadas aos parceiros da editora Trip e aos amigos, versus os jornalistas típicos, que seriam todos os demais. Elas não comungam com "eles", porque sua postura profissional bem como sua rotina na revista são uma grande aventura, nada comum. Nesta dualidade "nós" versus "eles", este "nós" (a redação de TPM) é tão mitificado quanto a imagem da repórter aventureira. No discurso, a redação até segue um roteiro cotidiano, com reuniões de pauta, por exemplo, mas o dia-a-dia da revista também é peculiar, pontuado por eventos não-jornalísticos, que demarcam um coletivo profissional extraordinário - além do ordinário da vida e da profissão jornalística. O exercício do jornalismo idealizado em TPM é, principalmente, viver em clima de grande diversão, em sintonia com o estilo de vida que as narradoras dizem ter - fora do padrão, olimpiano.

\subsection{Dona do próprio destino}

É de se supor que mulheres que se apresentam como singulares e contrárias ao padrão estabelecido façam escolhas surpreendentes. Mas há uma sutileza no sentido que denominamos 
"donas do próprio destino", verificado em 9,5\% das SDs analisadas: as narradoras evocam um discurso feminista sobre as potencialidades de superação da mulher para redefinir seus papéis na sociedade e também enfatizam uma fala coletiva, que responde por uma geração ou mesmo pelas mulheres em geral. $O$ "nós" implícito nas falas seguintes é predominantemente inclusivo, abrangendo também leitoras, gerações, a população feminina - em oposição aos homens.

Nossa geração, a geração de quem hoje tem 40 , embora muita gente não acredite, foi criada para ser esposà, mãe, no máximo, professora primária. Qualquer homem se contentaria com seu destino social se ele fosse confortável e tivesse sido estabelecido há milênios. Mas nós não. Talvez tenhamos sido a última geração a carregar essa herança, mas o fato é que, profissionalmente falando, não se esperava muito de cada uma de nós. A verdade, entretanto, é que, nesse mundo masculinamente racional, temos folgado bastante (SD5)

Frente, a um suposto roteiro previsível, as narradoras de TPM afirmam ter mudado o próprio rumo. A conquista de ser dona do próprio 62 destino, reinventando seu caminho ou reciclando papéis predefinidos, é o sentido nuclear que atravessa o discurso: fazer novas e surpreendentes escolhas para vencer entre os homens, ignorando tradições ou convenções. Toma forma aí uma posição combativa, que critica as funções sociais e os modelos de comportamento atribuídos às mulheres, bem como as atitudes masculinas em relação a elas, reafirmando, implícita ou explicitamente, a urgência de buscar novas possibilidades de se fazer respeitar e ouvir na sociedade.

1-Eu sou feminista. Não só eu, como também a TPM. 2-Aprendi o que é feminismo, finalmente. Feminista é quem não acredita no patriarcado (aquele velho esquema em que os homens mandam) e tenta, de alguma maneira, fazer com que as coisas mudem. Dito isso, concluí que sou, sim, feminista. Claro que sou! Eu não acho que os homens devam decidir se a gente vai ou não fazer um aborto. Não acho que é certo a gente ganhar fama de mal comida ou de quem deu pro chefe quando é promovida no trabalho... Então, sou feminista. (SD85)

Trata-se, portanto, de se situar fora dos padrões - os papéis e valores tradicionalmente atribuídos às mulheres -, mas tendo os homens como referência, positiva ou negativa, para as escolhas a fazer. Esta 
FD deve ser compreendida no contexto de construção dos gêneros masculino e feminino, resultantes de um complexo processo social, cultural e político que define o que é ser homem e ser mulher em cada sociedade e período (NICHOLSON, 2000; SCOTT, 1995), estabelecendo predicados concernentes a cada sexo que foram cristalizados pela cultura de massas, em que o jornalismo tem papel decisivo. O discurso de TPM pode ser visto como um questionamento aos papéis naturalizados como fenininos. Ao menos no que tange à FD "dona do próprio destino", é inegável que a fala das narradoras não apenas trata de temas femininos, mas os coloca em questão, como preconiza Higonnet (1991), indo além dos temas individuais para problematizar a condição feminina, como rcivindicava Buitoni (1990).

\subsection{Solteira orgulhosa}

As solteiras têm espaço cativo em $T P M$. No discurso que perpassa a fala das supostamente descomprometidas, emerge a mulher "solteira orgulhosa", tomando de empréstimo uma expressão cunhada pela revista para esta formação discursiva presente em $8,5 \%$ das SDs. Esta FD oscila entre incensar e ironizar a própria condição amorosa: ora as narradoras parecem orgulhosas da vida descompromissada que levam, ora orgulhosas demais para dar mostras de que desejariam ter um par. A mulher solteira de TPM transita entre estes opostos, como exemplificam as SDs abaixo:

Às vezes, é duro ser mulher. Às vezes é muito amargo o preço da vida doce das messalinas erráticas. Dói no bolso c no coração. $E$ ainda tem uns homens que nos dizem "comecei a vida feminista e terminei misógino". Seja lá como for, o feminismo já cra, sexo frágil é sexo forte, temos direitos e deveres iguais faz tempo, e podemos propor que, em nome das multas por alta velocidade pra chegar mais rápido nas mesas e festas, nossos amiguinhos nos convidem para muitos, talvez todos os drinks. Um brinde! (SD254)

Nós, solteiros orgulhosos, acreditamos no amor. E por isso mesmo achamos que não devemos namorar qualquer um só para dar a sociedade (tias, avós, mães, colegas de trabalho) a resposta de que "sim, temos namorado!". (SD284)

O discurso construido indica as solteiras como locutoras e as casadas como alteridade: clas são a referência que perpassa a construção 
de sentidos. Portanto, é também como se posicionam em relação às mulheres comprometidas que as narradoras constroem a imagem da própria solteirice:

Taí a origem da riqueza dos homens e das mulheres casadas, logo 0 nosso desequilíbrio financeiro: a gente sai demais. Cientes disso, as malditas seguradoras de carro não negociam conosco. Quando pedi desconto ao preço salgadíssimo, a moça do outro lado da linha me disse, "olha, com esse teu perfil, jovem e solteira, fica mais caro mesmo. Você deve sair muito à noite, sabe como é...", "sei, vocês acham que eu vivo de festa em festa, de bar em bar, logo corro mais risco de causar um sinistro", ela riu, "é mais ou menos isso...". (SD253)

A comida era ótima. Mas na hora que trouxeram o meu risoto de funghi trufado eu quase passei mal de enjôo. A comida era ótima. Mas casais chegavam animados. Apesar de não ter inveja deles (eu juro), isso mais o piano bar tocando bossa nova foram me dando um ataque súbito de melancolia. $\mathrm{E}$ os garçons continuavam vindo toda a hora falar comigo. Cheguei a pensar que era pena, mas era "fineza" mesmo. Sim, minha paranóia atingia graus exorbitantes. Tanto que rejeitei a sobremesa (sim, uma sobremesa que devia ser maravilhosa). E só tomei um café. Saí fugida, mal-educada, sem dar tchau. (SD292)

O discurso constrói a representação de mulheres solteiras $\mathrm{em}$ relação ao universo das casadas, reiterando a mesma tensão dos diferentes tipos de orgulho: ambas têm motivos para invejar a outra. A casada deve invejar a vida de festas e possibilidades de sexo da solteira; já esta deve invejar a estabilidade financeira e emocional da casada. A "solteira orgulhosa" constitui-se em um tensionamento de sentidos, da mulher sozinha à procura de um amor, mas com identidade própria $\mathrm{e}$ capaz de viver bem sem um parceiro - ainda que temporariamente. A posição de TPM em relação aos modelos historicamente construídos é também de tensionamento: rompe com a idéia absoluta de que a mulher precisa ter um homem e viver em função dele, embora:flerte com a concepção de realização pessoal imbricada ao êxito no amor, como parte do saber-viver feminino (MORIN, 2005). Mas passa ao largo de fórmulas explícitas para conquistar e manter seu homem: neste quesito, a "solteira orgulhosa" de TPM parece se constituir mais como sujeito dos seus desejos do que como objeto dos desejos masculinos. Em 
comparação com as demais revistas femininas, seria, portanto, uma solteira predominantemente fora dos padrões.

\section{A ruptura que não rompe}

A revista $T P M$ anuncia reitcradamente constituir-se como um foco de resistência ao formato pedagógico e autoritário historicamente consolidado na imprensa feminina. A pergunta que atravessa cste artigo é se trata-se ou não de uma revista de ruptura. Buscamos responder a essa questão a partir da marca inegavelmente distintiva de TPM, no escopo da imprensa feminina, e em relação à narrativa jornalistica tradicional: a ênfase $\mathrm{cm}$ quem conta as histórias. Se comprcendemos o jornalismo como construtor da realidade e, muitas vezes, a forma mais acessivel de vivenciar experiências do outro, é possivel afirmar que, em TPM, essa mediação é explícita: tem nomes, corpos, histórias e visões de mundo.

As narradoras da revista são os modelos legitimados frente às leitoras, até pela força da repetição - elas são os personagens constantes ou reincidentes8. Em TPM, não há ruptura com a simulação de conversa intima, apenas uma nova versão dessa simulação, que desnuda narradoras, uma vez que elas deixam de se configurar apenas como contadoras de histórias para serem também contadoras das suas próprias histórias.

Com o foco $\mathrm{cm}$ quem cstas narradoras dizem ser, a análise apontou seis formações discursivas que correspondem a ideais femininos ora convergentes com a idéia de ruptura, ora contrários. As duas FDs predominantes aparentemente produzem sentidos opostos. A "mulherzinha" atualiza modelos que vêm sendo formatados há séculos, reiterando a idéia de uma mulher multifuncional, sensivel, maternal, movida pelas preocupações amorosas e valorizada pela competência doméstica e o cuidado com o corpo. A "fora do padrão", ao contrário, desconstrói características culturalmente estruturadas, destacando a singularidade. Contudo, aproxima-se da "mulherzinha" quando determina que é preciso ser diferente para ter a incensada autenticidade: apresenta mais uma regra do saber-viver em que não basta ser você mesma, é preciso "ser fora do padrão" - pois ser fora do padrão é $O$ padrão de reconhecimento das mulheres de TPM. 
TPM também evoca o formato tradicional das revistas femininas na FD "sábia e experiente", por meio da qual quem narra se sente à vontade para julgar e aconselhar. Rompe-se com a hegemonia dos especialistas para normatizar o exercício da feminilidade - as narradoras legitimam sua fala taxativa por meio de sua experiência de vida, como mãe, profissional e esposa. Mas a sabedoria acumulada das narradoras muitas vezes sugere à leitora o lugar de aprendiz, tal qual a fala pedagógica de outras publicações femininas.

Também ao assumir a posição de jornalistas, as narradoras baseiam-se em sua própria experiência de vida. Ser "repórter aventureira" remete à idéia do exercício do jornalismo como uma emoção extra em uma vida plena de momentos divertidos e surpreendentes. A mitificação da imagem da repórter se dá com base na configuração das narradoras como heroínas de suas próprias vidas em um falar de si que comunga com a espetacularização da vida privada. Como narradorasolimpianas, disputam as atenções das leitoras com os entrevistados da revista.

O desejo de ruptura às convenções perpassa a formação discursiva "dona do próprio destino", que evoca um discurso inclusivo, que tem como alteridade os homens. Remete-se à proposição de que as mulheres devem fazer escolhas surpreendentes para vencer em um mundo em que eles (ainda) mandam: questionando papéis e atribuições supostamente imanentes ao feminino, é inegável que esta FD formula um discurso de resistência, além de problematizar as questões femininas em contraponto às críticas de que revistas para mulheres listam temas caros a este universo sem, contudo, questioná-los.

A FD "solteira orgulhosa", por sua vez, rompe com a idéia de que ter um homem ao lado é condição obrigatória para felicidade ao revelar solteiras capazes de viver bem sozinhas - ainda que provisoriamente, uma vez que flerta com a idéia de realização pessoal imbricada à conquista amorosa. Há, contudo, uma evidente ruptura com a mulher que fazia escolhas, cuidava do corpo e do lar principalmente em função de um homem - a "solteira orgulhosa" de $T P M$ é sujeito de seus desejos.

$T P M$ é, portanto, uma revista de ruptura? Em parte sim, ao construir a imagem de mulheres-sujeito, donas dos seus destinos e vontades; ao questionar os papéis e os atributos femininos culturamente construídos; ao pluralizar as imagens femininas, evocando modelos 
além da fêmea bela e multifuncional. Rompe também com a ditadura dos especialistas como detentores do saber que deve regrar o exercício da feminilidade, além de desfazer as amarras de uma escritura esquemática que rege os textos no jornalismo de referência e demanda o apagamento da figura do narrador.

Mas, em parte, não é uma revista de ruptura. TPM atualiza padrões consolidados, ao reinventar o formato pedagógico e normativo mascarado pela informalidade e a simulação de intimidade; ao evocar estereótipos que naturalizam determinados atributos como tipicamente femininos; ao estipular a diferença como regra. A partir daí, identificamos na fala auto-referente das narradoras de TPM um discurso tão autoritário quanto o que apaga as marcas do narrador e faz crer ter emergido diretamente dos fatos, bem como aquele, típico da imprensa feminina, que usa verbos no imperativo para dizer como a mulher deve ser mulher. Substitui-se a construção narrativa da suposta realidade, como se convencionou no jornalismo de referência e nos manuais utilitários característicos das revistas femininas, pela explicitação, muitas vezes, de uma verdade autocentrada, parcial e glamourizada. Face à reconhecida atuação da imprensa na construção de identidades femininas percebidas, as narradoras carregam em seu discurso a predisposição de conformarem leitoras à sua imagem: fazem imprensa feminina à moda antiga, sob a roupagem moderna e descolada de quem foge ao padrão apenas para reafirmá-lo.

\section{Referências}

BENETTI, Marcia. Jornalismo e perspectivas da enunciação: uma abordagem metodológica. Intexto, $n^{\circ} 14$. Porto Alegre: UFRGS, 2006. Disponivel em: www.intexto.ufrgs.br

BENJAMIN, Walter. O narrador - considerações sobre a obra de Nicolai Leskov. In: BENJAMIN, Walter. Magia e técnica, arte e politica. São Paulo: Brasiliense, 1985.

BENVENISTE, Émile. Problemas de linguiistica geral 1 . Campinas: Pontes Editores, 2005

BORNEUF, Roland. OUELLET, Réal. O universo do romance. Coimbra: Livraria Almedina, 1976.

BRAGA, Adriana. Corpo e agenda na revista feminina. Cadernos idéias I U H, ano 3, $n^{\circ} 40,2005$. Disponivel em: http:// 
www.unisinos.br/ihu/publicacoes/cadernos_ideias/edicao00040.pdf Acesso em 15 de março de 2006.

. Desafio de Verão; agendamento corporal na imprensa feminina. Anais do XXVI Congresso Brasileiro de Ciências da Comunicação - Intercom. Belo Horizonte, 2003.

BUITONI, Dulcília. Imprensa feminina. São Paulo: Ática, 1990.

BUITONI, Dulcília. Mulher de papel. São Paulo; Loyola, 1981.

FONTCUBERTA, Mar de. La noticia. Barcelona: Paidós, 1993.

FUJISAWA, Marie Suzuki. Das Amélias às Mulheres Multifuncionais. São Paulo: Summus Editorial, 2006.

HIGONNET, Anne. Mulheres, imagens e representações. In: DUBY, Georges; PERROT, Michelle. História das mulheres; o século XX. Porto: Edições Afrontamento, 1991.

LEITE, Ligia Chiappini Moraes. O foco narrativo. São Paulo: Ática, 2005.

MAINGUENEAU, Dominique. Novas tendências em análise do discurso. Campinas: Pontes, 1997.

MAINGUENEAU, Dominique. Análise de textos de comunicação. São Paulo: Cortex Editora, 2005.

MEDINA, Cremilda. Povo e personagem. Canoas: Editora da Ulbra, 1996.

MIRA, Maria Celeste. O leitor e a banca de revistas - $A$ segmentação da cultura no século XX. São Paulo: Olho D'Água, 2003.

MOTTA, Luiz Gonzaga. Narratologia - Análise da narrativa jornalística. Brasilia: Casa das Musas, 2004.

MORIN, E. Cultura de massa no século XX: o espírito do tempo. vol 1, Rio de Janeiro, Forense Universitária, 1987.

NICHOLSON, Linda. Interpretando o gênero. Estudos Feministas. Ano 8. $2^{\circ}$ semestre, 2000. Disponível em: http:// portalfeminista.org.br Acesso em: 10 de janeiro de 2006

ORLANDI, Eni. Análise de discurso. Campinas: Pontes, 2005. A incompletude do sujeito. In: ORLANDI, Eni (org.). Sujeito e texto. São Paulo: EDUC, 1988.

PASSERINI, Luísa. Mulheres, consumo e cultura de massa. In: DUBY, Georges; PERROT, Michelle. História das mulheres; o século XX. Porto: Edições Afrontamento, 1991.

PÊCHEUX, Michel. Análise automática do discurso. In: GADET, F. e HAK, T. (orgs). Por uma análise automática dos discurso 
- Uma introdução à obra de Michel Pêcheux. São Paulo: Editora da Unicamp, 1990.

RESENDE, Fernando. O olhar às avessas - A lógica do texto jornalistico. Tese de doutorado. Escola de Comunicações e Artes da Universidade de São Paulo: São Paulo, 2002.

RODRIGUES, Adriano. Delimitação, natureza e funções do discurso midiático. In: MOUILLAUD, Maurice; PORTO, Sérgio (org). O jornal: da forma ao sentido. Brasília: Paralelo, 15, 1997.

SANTIAGO, Silviano. O narrador pós-moderno. In: SANTIAGO, Silviano. Nas malhas da letra. Rio de Janeiro: Rocco, 2002.

SCOTT, Joan. Gênero: uma categoria útil de análise histórica. Educação \& Realidade, v. 20, n², jul/dez, 1995. Porto Alegre.

SERRA, Sônia. Relendo o gatekeeper: notas sobre condicionantes no jomalismo. São Bernardo do Campo, Compós, 2004. Disponivel em: http://www.ufrgs.br/gtjornalismocompos/doc2004/ soniaserra2004.doc

TRAQUINA, Nelson. Teorias do jornalismo: porque as noticias são como são. Florianópolis: Insular, 2005.

VIZEU, Alfredo. O lado oculto do telejornalismo. Florianópolis: Calandra, 2005.

\section{Notas}

1 Na edição de estréia, TPM reproduziu trechos de outras revistas femininas, de diferentes épocas, ironizando as dicas de como ficar bonita e conquistar/manter seu homem com o título: "Eu não sou cachorra กล̃o".

2 Conceito criado por Morin (1987) para designar as celebridades transformadas em seres "sobre-humanos" pela cultura de massas. A mídia seria responsável por revesti-los de uma aura mítica e, ao mesmo tempo, fazer de suas vidas privadas atração e modelos de identificação.

3 À exceção da seção Botica, que responde dúvidas sobre cuidados com a beleza, em TPM os especialistas via de regra resumemse à condição de entrevistados nas matérias de capa e uma ou duas secundárias.

4 Com a diversificação das formas narrativas, o narrador clássico, que dá a seu ouvinte a oportunidade de intercambiar experiências, como preconiza Benjamin (1985), evoluiu para o narrador do romance, que 
, não mais falava de forma exemplar ao leitor; e, por último, o narrador que, como o jornalista, "só transmite pelo narrar a informação, visto que escreve não para narrar a ação da própria experiência, mas o que aconteceu com X ou Y em tal lugar e a tal hora" (SANTIAGO, 2002, p. 45-46).

$5 \mathrm{~A}$ análise inclui reportagens (foram contabilizados como textos independentes as matérias secundárias de uma reportagem maior), entrevistas, notas, as colunas de Milly Lacombe (Coluna do Meio), de Mara Gabrilli (Um Pensamento), de Antonia Pellegrino e Sabrina Anzuategui (identificadas, respectivamente como "a solteira" e "a casada"), a seção Badulaque, com paginação e papel diferenciados e edição da repórter especial Nina Lemos, e também a seção Editoras Convidadas, em que há um rodízio de colaboradoras falando de seus momentos de vida, seus gostos e indicando produtos e serviços que elas aprovam.

6 As SDs apresentadas têm caráter ilustrativo: não correspondem à totalidade das SDs analisadas.

7 Como uma mesma seqüência discursiva pode conter sentidos que apontem para mais de uma formação discursiva, o somatório das porcentagens representativas de cada FD, apresentadas ao longo deste capítulo, excede a soma de $100 \%$.

8 Mesmo na seção Editoras Convidadas, marcada pela alternância de colaboradoras, a repetição de nomes é freqüente. 